\title{
Postnatal development and testosterone dependence of a rat epididymal protein identified by neonatal tolerization
}

\author{
S. A. Joshi, S. Shaikh, S. Ranpura and V. V. Khole* \\ Hybridoma Division, National Institute for Research in Reproductive Health, \\ Jehangir Merwanji Street, Parel, Mumbai 400 012, India
}

\begin{abstract}
A rat epididymal protein of $27 \mathrm{kDa}$ was identified using neonatal tolerization. This study reports the production and characterization of a polyclonal antiserum to this protein. ELISA was used to demonstrate that this antiserum reacts strongly with epididymal sperm proteins, but has little or no reactivity with testicular proteins. Western blot analysis revealed that this polyclonal antiserum recognized a $27 \mathrm{kDa}$ protein extracted from the corpus epididymidis as well as from spermatozoa from the corpus and cauda epididymides, and immunostaining revealed the presence of the protein in the corpus to cauda epididymides. Stronger reactivity was observed in the supranuclear region and stereocilla of principal cells of the corpus epididymidis and in the luminal content of the corpus and cauda epididymides. The testicular section showed no reactivity. Treatment with the antiserum resulted in time- and dosedependent agglutination of rat spermatozoa. By indirect
\end{abstract}

immunofluorescence, the antiserum localized proteins in the mid-piece region of rat spermatozoa. Studies were carried out to determine the age at which the protein first became apparent during postnatal development. The protein was expressed from day $\mathbf{4 0}$ onwards, as demonstrated by western blot analysis. The androgen regulation of this protein was ascertained by castration and supplementation studies. Expression of this protein showed a decline starting at day 14 after castration and by day 21 the protein was absent; however, androgen replacement resulted in the reappearance of the protein. The results of these studies indicate that the protein identified is specific to the epididymis, and is regulated by development and androgens. The importance of epididymis-specific proteins that are regulated by androgens in sperm maturation is discussed, and the need to ascertain the sequence of the protein and clone the cognate gene is indicated.

\section{Introduction}

Although mammalian spermatozoa are highly differentiated when they leave the testis, they are functionally immature and need to undergo a series of complex and sequential events during their journey through the epididymis to acquire maturity. During the time spent in the epididymis, spermatozoa acquire the capacity for vitellus fusion, penetration and fertilization (Amann et al., 1993; Cooper, 1986, 1995). Several proteins synthesized in the epididymis, such as the product of the CRES gene, HE4 and Clusterin (Kirszbaum et al., 1989; Kirchhoff et al., 1991; Cornwall et al., 1992) have been shown to play an important role in protection of spermatozoa during their storage.

Spermatozoa are known to acquire different functions as they move through the different regions of the epididymis. It has been shown experimentally that it is in the corpus epididymidis that spermatozoa acquire the ability to bind to the zona pellucida, and acquire

\footnotetext{
*Correspondence

Email: hybridoma@rediffmail.com
}

motility and fertilizing potential (Dacheux et al., 1987; Moore, 1998; Burkin and Miller, 2000). Rat epididymal protein DE and human homologue (AEGL1) of rat acidic epididymal glycoprotein play an important role in sperm-egg fusion in mice (Hayashi et al., 1996; Chen et al., 1999). Human FLB1, an epididymal protein, is involved in sperm-oocyte recognition (Boue et al., 1995). Batova et al. (1998) showed that human epididymal sperm surface glycoprotein is involved in sperm-zona pellucida interaction in humans.

There are several direct and indirect studies that underline the importance of epididymal antigens in reproduction. It has been suggested that incomplete sperm maturation within the epididymis is responsible for total failure of sperm binding to the zona pellucida in unsuccessful IVF treatments in humans (Bedford and Kim, 1993). In fact, a high percentage of male infertility in humans is believed to originate from the malfunction of the epididymis (Lunde et al., 1990). Blaquier et al. (1987) have shown by flow cytometric analysis that there is decreased and altered localization of epididymal antigens in infertile patients. Human $\mathrm{P} 34 \mathrm{H}$ protein, which is involved in sperm-zona pellucida interaction, is less abundant in some cases of idiopathic infertility 
(Boue and Sullivan, 1996). P25b and P21b proteins (bull homologues of human $\mathrm{P} 34 \mathrm{H}$ ) are associated with subfertility and their expression is markedly low in the subfertile bull (Parent et al., 1999). It is speculated that epididymal antigens play a predominant role in some types of human infertility (Poulton et al., 1996). In view of these results it is clear that epididymal proteins have a vital role in maturation of spermatozoa, leading to successful reproduction and, therefore, more attention needs to be focused on identification of epididymal antigens.

Identification of newer epididymis-specific proteins by conventional methods, such as hybridoma technology, has not been very successful, probably because the testicular proteins are more immunogenic than are the epididymal proteins. Therefore, an alternative method of 'neonatal tolerization', used for the first time by Ensrud and Hamilton (1991) for identification of epididymal antigens, was used in the present study with slight modifications (Khole et al., 2000). In this study, animals were tolerized to testicular sperm protein (tolerogen) at birth and were then immunized with epididymal sperm protein (immunogen) to raise a specific immune response. Serum samples from these neonatally tolerized and immunized mice were used to identify a dominant epididymis-specific protein with a molecular mass of approximately $27 \mathrm{kDa}$. This protein was used to raise polyclonal antibodies in rabbits. The aim of the present study was to characterize this antibody and investigate the tissue specificity, regional differences, androgen dependence and ontogeny of this protein.

\section{Materials and Methods}

\section{Animals}

Mature inbred male Holtzman rats weighing 180$220 \mathrm{~g}$ and virgin Belgium white female rabbits weighing $2.5-3.0 \mathrm{~kg}$ were housed in the animal house of the institute with food and water available ad libitum. The experimental protocol of this study was approved by the Ethics Committee for Care and Use of Laboratory Animals for Biomedical Research of the National Institute for Research in Reproductive Health (Mumbai).

\section{Reagents}

Adjuvants and dihydrotestosterone (DHT) were obtained from Sigma (St Louis, MO). All the reagents for electrophoresis, western blot analysis and ELISA were obtained from SRL India Ltd (Mumbai). Nitrocellulose sheets were obtained from Amersham (Buckinghamshire), conjugates from Bangalore Genei India Ltd (Bangalore), ELISA plates from Nunc (Roskilde), and Silastic tubing and medical grade adhesive from Dow Corning (Midland, MI).

\section{Preparation of testicular and epididymal sperm protein}

Rat testicular and epididymal sperm proteins were prepared using the method described by Khole et al. (2000). Briefly, cauda epididymides were removed from four rats. They were placed into Ham's F10 medium and stored at $37^{\circ} \mathrm{C}$ for $30 \mathrm{~min}$. The supernatant was collected and centrifuged at $520 \mathrm{~g}$ for $20 \mathrm{~min}$. The pellet was washed twice with medium and then resuspended in PBS, and sonicated for $5 \mathrm{~min}$. The suspension was centrifuged at $2790 \mathrm{~g}$ for $20 \mathrm{~min}$ and the supernatant was used as rat cauda epididymal sperm protein. The protein content of both testicular and epididymal sperm protein was estimated by the method described by Lowry et al. (1951).

\section{Protocol for neonatal tolerization}

Neonatal tolerization was carried out using the protocol described by Khole et al. (2000). Briefly, $12 \mathrm{Balb} / \mathrm{c}$ neonates (female) were injected i.p. with $20 \mu \mathrm{g}$ tolerogen (rat testicular protein) in $50 \mu \mathrm{l}$ PBS within $24 \mathrm{~h}$ of birth. On day 5, Balb/c neonates received a further i.p. injection of tolerogen $(20 \mu \mathrm{g}$ per $50 \mu \mathrm{l})$. Blood samples were collected through the retro-orbital plexus on day 21 to obtain the tolerization serum samples. On day 21, these tolerized animals were divided into two groups each containing six animals. Animals from group 1 were immunized s.c. at multiple sites with tolerogen $(100 \mu \mathrm{g}$ per $100 \mu \mathrm{l}$ in PBS) emulsified with Freund's complete adjuvant (FCA). Animals from group 2 were immunized with immunogen (rat epididymal sperm protein $(100 \mu \mathrm{g}$ per $100 \mu \mathrm{l}$ in PBS) emulsified in FCA. Two boosters were administered at intervals of 2 weeks and 1 week after the last booster was administered, blood samples were collected from all the animals through the retro-orbital plexus to obtain the tolerized and immunized serum samples.

\section{Antibody production}

Polyclonal antibody (Pab) to the $27 \mathrm{kDa}$ rat epididymal protein identified using sera from mice that were neonatally tolerized against testicular protein and immunized with epididymal protein was raised in virgin female Belgium white rabbits, the preimmune sera of which showed no inherent crossreactivity with rat testicular or epididymal proteins. The protein band corresponding to the $27 \mathrm{kDa}$ protein was excised from eight preparative SDS-PAGE gels (each gel containing $3 \mathrm{mg}$ total rat cauda epididymal sperm protein) stained with Coomassie brilliant blue R-250; the stain was removed with destainer $(5: 4: 1$, methanol:distilled water:glacial acetic acid). This protein band was the dominant band that was immunolocalized by sera of all the mice that were tolerized with testicular protein neonatally and immunized with epididymal protein (Khole et al., 2000). 
The identified band was used for immunization of rabbits in the method described by Rankin et al. (1992). Briefly, the band was homogenized thoroughly in $3 \mathrm{ml}$ PBS at $\mathrm{pH}$ 7.4. One half of this homogenate was emulsified with $1.5 \mathrm{ml}$ FCA and injected s.c. at multiple sites. Two booster doses, each containing one half of the remaining homogenate in Freund's incomplete adjuvant, were administered at intervals of 15 days and blood samples were collected from rabbits on day 8 after the last booster. The serum samples were then analysed for immunoreactivity by both ELISA and western blot analysis.

\section{ELISA}

In ELISA, both rat testicular and epididymal sperm proteins $(10 \mu \mathrm{g}$ per well) diluted in carbonate-bicarbonate buffer, $\mathrm{pH}$ 9.6, were coated on to flat-bottomed 96well microtitre plates and incubated overnight at $4{ }^{\circ} \mathrm{C}$. Non-specific binding sites were blocked by incubating the wells in $2 \%(\mathrm{w} / \mathrm{v})$ non-fat dry milk (NFDM) in PBS for $1 \mathrm{~h}$ at $37^{\circ} \mathrm{C}$. The wells were washed three times for 5 min each with PBS containing $0.05 \%(\mathrm{v} / \mathrm{v})$ Tween 20, and then incubated with $100 \mu \mathrm{l}$ immune sera that was serially diluted between $1: 1000$ and $1: 32000$ in $0.2 \%$ NFDM in PBS for $1 \mathrm{~h}$ at $37^{\circ} \mathrm{C}$. The wells were then washed as described above and incubated with 1:5000 dilution of goat anti-rabbit IgG labelled to horseradish peroxidase (HRP) for $1 \mathrm{~h}$ at $37^{\circ} \mathrm{C}$. The wells were washed three times as described earlier and the immunoreactivity was visualized using $200 \mu \mathrm{l}$ substrate solution $(8 \mathrm{mg}$ orthophenylenediamine dihydrochloride $+0.03 \%(\mathrm{v} / \mathrm{v})$ $\mathrm{H}_{2} \mathrm{O}_{2}$ in 0.1 mol citric acid $\mathrm{I}^{-1}$ and 0.2 mol disodium hydrogen orthophosphate $\mathrm{I}^{-1}$ ). The absorbance at $492 \mathrm{~nm}$ was measured in a Titertek multiscan plate reader (SLT Instruments, Grodig).

\section{SDS-PAGE and western blot analysis}

SDS-PAGE and western blot analysis were carried out to determine the molecular mass of the protein identified by the Pab, to study the distribution of the protein in spermatozoa and in tissue from different regions of the rat epididymis, namely caput, corpus and cauda epididymides and somatic and accessory gland proteins. Epididymides from four rats were excised and dissected into caput, corpus and cauda epididymides. Spermatozoa from these regions were separated as described earlier by mincing the tissue in Ham's F10. Sperm proteins were extracted in $1 \%(\mathrm{w} / \mathrm{v})$ SDS by sonication for $5 \mathrm{~min}$. The minced tissues were then washed repeatedly with Ham's F10 to remove the residual spermatozoa. The respective tissues free of residual spermatozoa were then homogenized in $1 \%$ SDS for $5 \mathrm{~min}$. Protein from somatic tissues, namely brain, kidney, liver, spleen, thymus, heart and accessory reproductive tract organs, such as seminal vesicle and prostrate gland, were extracted by homogenizing the respective tissues in 1\% SDS for 5 min. Both tissue and sperm proteins were estimated by the method described by Lowry et al. (1951).

SDS-PAGE was carried out as described by Towbin et al. (1979) and $45 \mu \mathrm{g}$ of protein was loaded into each well. Western blot analysis was carried out according to the procedure described by Laemmli (1970) and $5 \%$ NFDM in PBS was used for blocking non-specific reaction. Nitrocellulose strips were incubated with primary antibody (1:10 000 dilution in $0.5 \%$ NFDM) for $1 \mathrm{~h}$ at room temperature. Strips were then washed three times with $0.5 \%$ Tween 20 in PBS and incubated with goat anti-rabbit HRP conjugate (1:1000 dilution in $0.5 \%$ NFDM) for $1 \mathrm{~h}$ at room temperature. Strips were washed again as described above and developed using $10 \mathrm{mg}$ 3,3-diaminobenzidine in $10 \mathrm{ml}$ of PBS containing $10 \mu \mathrm{l}$ of $30 \% \mathrm{H}_{2} \mathrm{O}_{2}$. Strips incubated with appropriately diluted preimmune sera were used as controls.

\section{Immunohistochemistry}

Whole rat epididymis and testis were fixed in Bouin's fixative for $24-48 \mathrm{~h}$. The tissues were embedded in paraffin wax and serial sections of $5 \mu \mathrm{m}$ were cut and placed on clean glass slides. Tissue sections were deparaffinized, rehydrated and incubated for $30 \mathrm{~min}$ in $0.3 \% \mathrm{H}_{2} \mathrm{O}_{2}$ in methanol to quench endogenous peroxidase activity. Non-specific reactivity was blocked with $2 \%$ BSA in PBS for $1 \mathrm{~h}$ followed by incubation in immune serum (1:50 dilution in $0.2 \% \mathrm{BSA}$ ) at $4{ }^{\circ} \mathrm{C}$ overnight. After sections were washed three times for $5 \mathrm{~min}$ in PBS, goat antirabbit HRP (1:250 dilution in 0.2\% BSA) was applied to the sections for $2.5 \mathrm{~h}$ at room temperature. All the incubations were performed in a humidified chamber. The slides were then washed as described above. Colour reaction was carried out using 3,3-diaminobenzidine + $\mathrm{H}_{2} \mathrm{O}_{2}$ (10 mg 3,3-diaminobenzidine $+10 \mu \mathrm{l} \mathrm{H}_{2} \mathrm{O}_{2}$ in $10 \mathrm{ml}$ PBS). The slides were washed in running tap water, counterstained with haematoxylin, dehydrated and then mounted in DPX mountant. Two sets of controls were used in these studies. In the first set of controls, the sections were incubated with preimmune serum (1:50 dilution in $0.2 \% \mathrm{BSA}$ ) and in the second set, the sections were incubated with buffer instead of serum.

Immunohistochemical analysis was also performed to analyse the crossreactivity of the Pab with rat somatic tissue, brain, kidney, liver, spleen, thymus and heart and the accessory reproductive tract tissue proteins, seminal vesicle and prostrate gland. The tissues were processed for immunohistochemistry as described earlier.

\section{In vitro agg/utination}

Sperm agglutination experiments were carried out in vitro by the method described by Castle et al. (1997). 

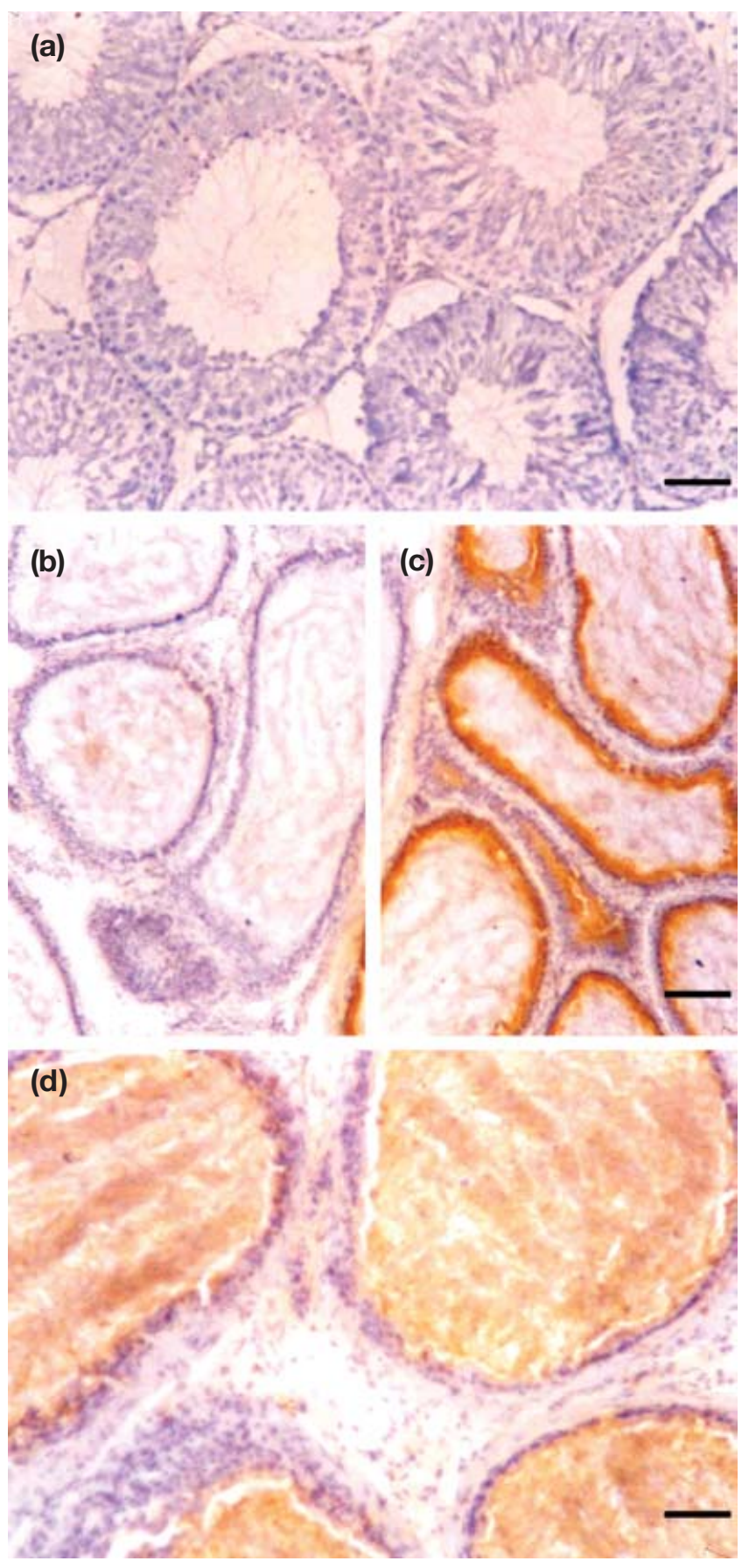

Fig. 1. Immunohistochemical analysis of the $27 \mathrm{kDa}$ epididymal protein in the (a) testis, and (b) caput, (c) corpus and (d) cauda epididymides of rats. No staining was seen in (a) the testis or (b) caput epididymidis. The protein is localized in (c) the corpus epididymidis and is also seen on the luminal contents of the (d) cauda epididymidis. Scale bars represent $100 \mu \mathrm{m}$.

Briefly, a tenfold serial dilution of Pab ( $7 \mathrm{mg}$ to $7 \mu \mathrm{g}$ ) was made in PBS. One part of antibody was mixed with one part of rat spermatozoa $\left(10^{8} \mathrm{cells}^{-1} \mathrm{ml}\right)$ in $200 \mu \mathrm{l}$ of reaction mixture. The final concentration of antibody in the reaction was $350.0 \mu \mathrm{g}$ to $0.35 \mu \mathrm{g}$. The agglutination was studied for 30 and $60 \mathrm{~min}$. Appropriately diluted preimmune serum was used for control experiments.

\section{Indirect immunofluoresence}

Spermatozoa from the rat cauda epididymides were washed with PBS and resuspended in the same buffer. Smears were prepared, air-dried and fixed with $0.025 \%$ $(\mathrm{v} / \mathrm{v})$ glutaraldehyde in PBS for $30 \mathrm{~min}$. The slides were then incubated for $1 \mathrm{~h}$ with $2 \%$ NFDM at room temperature and exposed to polyclonal antibody (1:50 dilution in $0.2 \%$ NFDM) overnight at $4{ }^{\circ} \mathrm{C}$. The next morning, the slides were washed with PBS and incubated for $2.5 \mathrm{~h}$ at room temperature with goat anti-rabbit IgG conjugated to fluorescein isothiocyanate (1:40 diluted in $0.2 \%$ NFDM). Slides were washed and examined under a Zeiss microscope equipped with epifluorescent optics. Appropriately diluted preimmune serum was used as control.

\section{Castration and DHT supplementation}

Mature male Holtzman rats ( $n=3$ per interval) were castrated under light ether anaesthesia. A small cutaneous incision was made in the scrotal skin and the testes were carefully exposed. The testicular artery was sutured and cut and then the testes were removed. The epididymides were returned to the scrotal cavity and the skin was sutured. Animals were killed at days 7, 14 and 21 after castration. Epididymides were excised, weighed and used for protein extraction in 1\% SDS containing protease inhibitors.

DHT supplementation was administered through a Silastic tube $(0.062$ inch internal diameter, 0.125 inch outer diameter) of $1 \mathrm{~cm}$ in length, filled with $6 \mathrm{mg}$ DHT and sealed with Silastic medical adhesive (Parte et al., 1992). The tube was implanted s.c. in the hind thigh pad. For DHT supplementation studies, castrated animals were divided into four groups, each comprising nine animals ( $n=3$ per interval). The groups were divided on the basis of the interval between castration and insertion of DHT implants. The implants were inserted on the day of castration (group 1), and at days 7 (group 2), 14 (group 3) and 21 (group 4) after castration. However, animals from all the groups were killed at days 7, 14 and 21 after the insertion of the implant. The epididymides were excised from all four groups, weighed and processed for SDS-PAGE and western blot analysis. Tissues from age-matched controls were processed in a similar way.

\section{Developmental expression study of protein}

Male rats of different ages (20, 30, 40, 50, 60 and 80 days of age) were killed and the epididymides were processed for SDS-PAGE and western blot analysis as described. 


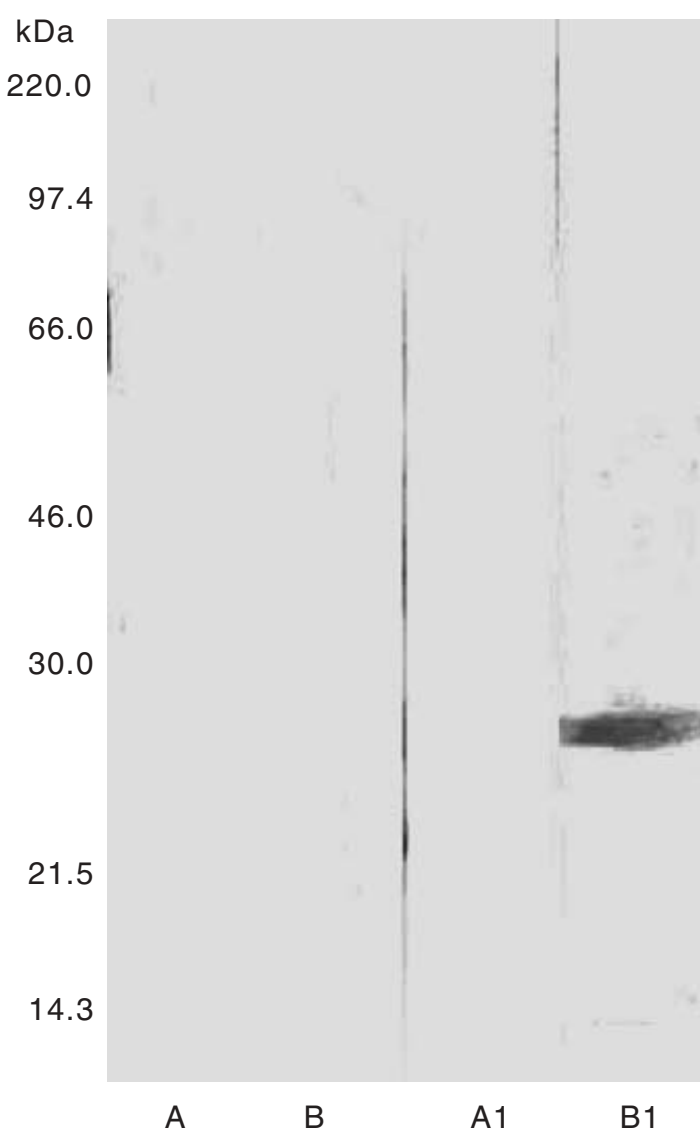

Fig. 2. Western blot analysis of rat testicular (lanes A and A1) and cauda epididymal sperm proteins (lanes B and B1) using polyclonal antibody. Rat testicular and cauda epididymal sperm protein were incubated with pre-immune (lanes A and B) or post-immune rabbit serum (lanes A1 and B1). Note no band was seen in testicular sperm protein extracts incubated with post-immune serum (lane A1) or in testicular sperm protein or cauda epididymal sperm protein incubated with preimmune serum (lanes A and B).

\section{Results}

\section{Characterization of polyclonal antibody}

The immunohistochemical localization of protein in the testis and different regions of the epididymis is shown (Fig. 1). Testis and caput epididymidis that were incubated with immune serum showed no reactivity (Fig. 1a,b), whereas there was strong reactivity in the corpus epididymidis (Fig. 1c). In this region, the protein was seen in the supranuclear region and stereocilia of principal cells. The protein was also detected in spermatozoa from corpus and cauda epididymides (Fig. 1d). No reaction was detected in any of the controls used in the study (data not shown).

Western blot analysis was carried out using rat testicular and cauda epididymal sperm protein (Fig. 2). Pab did not crossreact with testicular sperm protein and localized to a band at approximately $27 \mathrm{kDa}$ in the cauda epididymal sperm protein. Preimmune sera did (a)

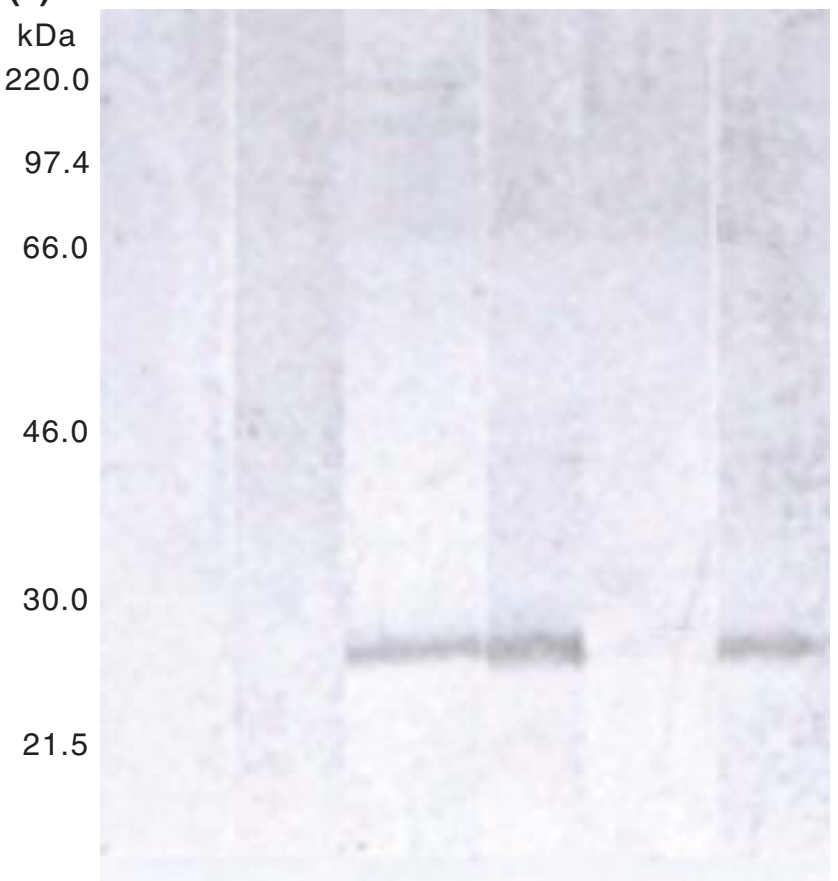

14.3

$\begin{array}{llllll}\text { A } & \text { A1 } & \text { B } & \text { B1 } & \text { C } & \text { C1 }\end{array}$

(b)

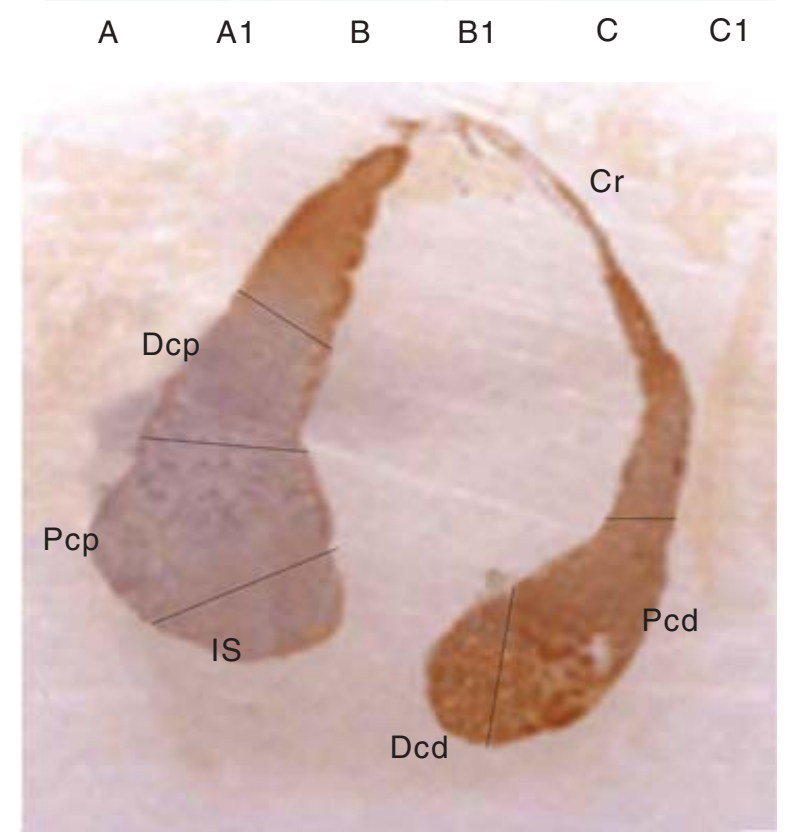

Fig. 3. (a) Western blot and (b) immunohistochemical analysis using polyclonal antibody of (a) lanes A, B and C: tissue protein from caput, corpus and cauda epididymides and lanes A1, B1 and C1: sperm protein from caput, corpus and cauda epididymides. (b) Note that the antibody localized a $27 \mathrm{kDa}$ band only in the tissue from the corpus epididymidis (lane B), spermatozoa from the corpus epididymidis (lane B1) and spermatozoa from the caudal epididymidis (lane C1). (b) Immunohistochemistry of whole epididymis (sagittal section) of an adult rat shows protein localization only in corpus $(\mathrm{Cr})$ and cauda epididymides. Dcd: distal cauda epididymidis; Dcp: distal caput epididymidis; IS: initial segment; Pcd: proximal cauda epididymidis; Pcp: proximal caput epididymidis. 

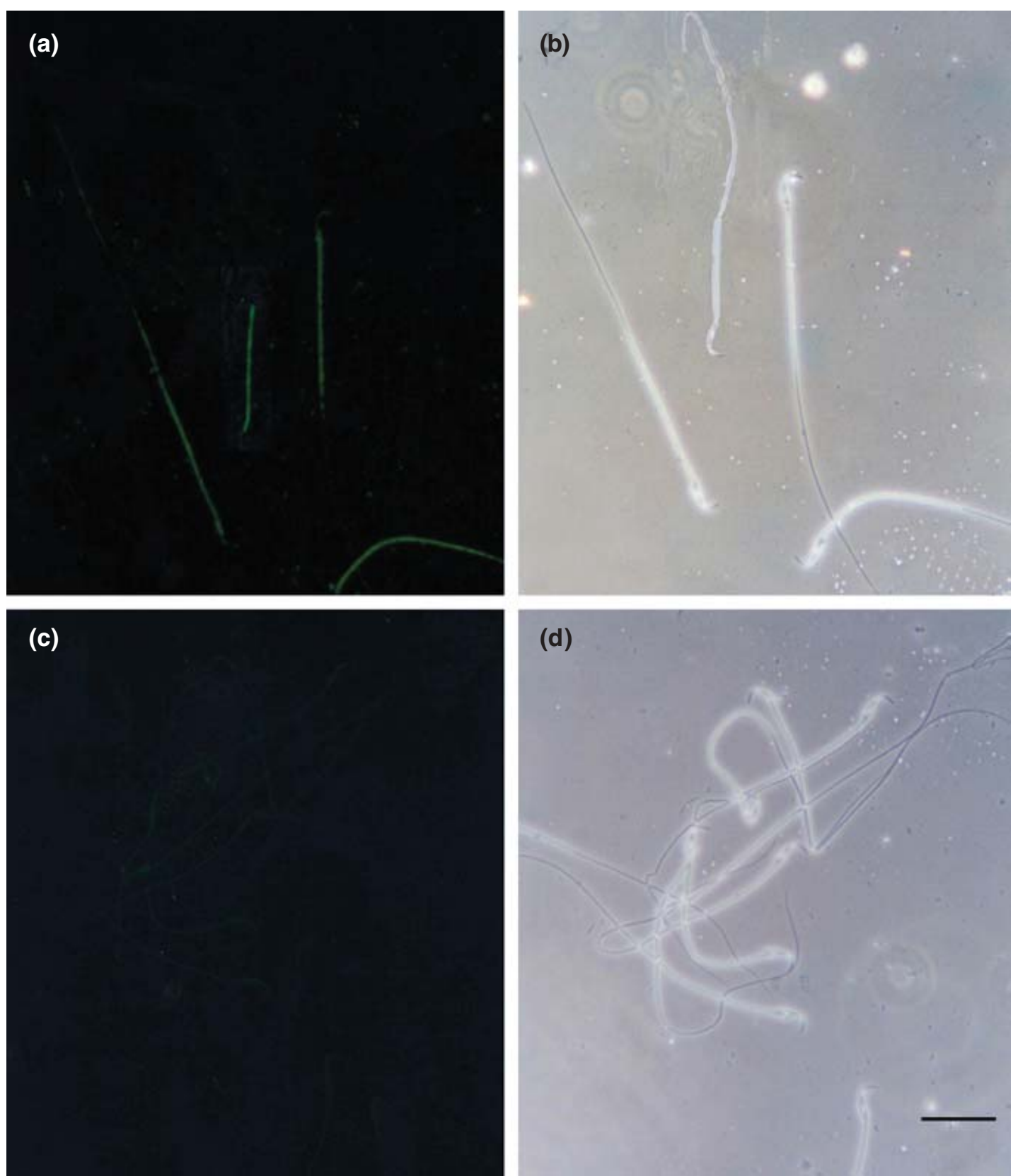

(d)

Fig. 4. Immunofluorescence localization of the $27 \mathrm{kDa}$ epididymal protein on spermatozoa from rat cauda epididymides. (a) Note fluorescent staining on the midpiece region of the spermatozoa incubated with the polyclonal antibody. (b) The corresponding phase-contrast image to (a). (c) There was no staining on spermatozoa when incubated with preimmune serum. (d) The corresponding phase-contrast image to (c). Scale bar represents $100 \mu \mathrm{m}$.

not show any crossreactivity against either testicular or cauda epididymal sperm protein.

Localization of the protein identified by Pab in different regions of the epididymis was demonstrated by western blot analysis (Fig. 3a). The Pab localized to a protein band in tissue proteins from the corpus epididymidis as well as from sperm proteins from corpus and cauda epididymides. However, the Pab did not react with any protein from either tissue or spermatozoa from the caput epididymidis or tissue from the cauda epididymidis. Similarly, region-specific localization of the protein in the sagittal section of the entire rat epididymides is shown (Fig. 3b). The protein was localized in corpus and cauda epididymides.

The indirect immunofluorescence localization on rat cauda epididymal spermatozoa is shown (Fig. 4). The 

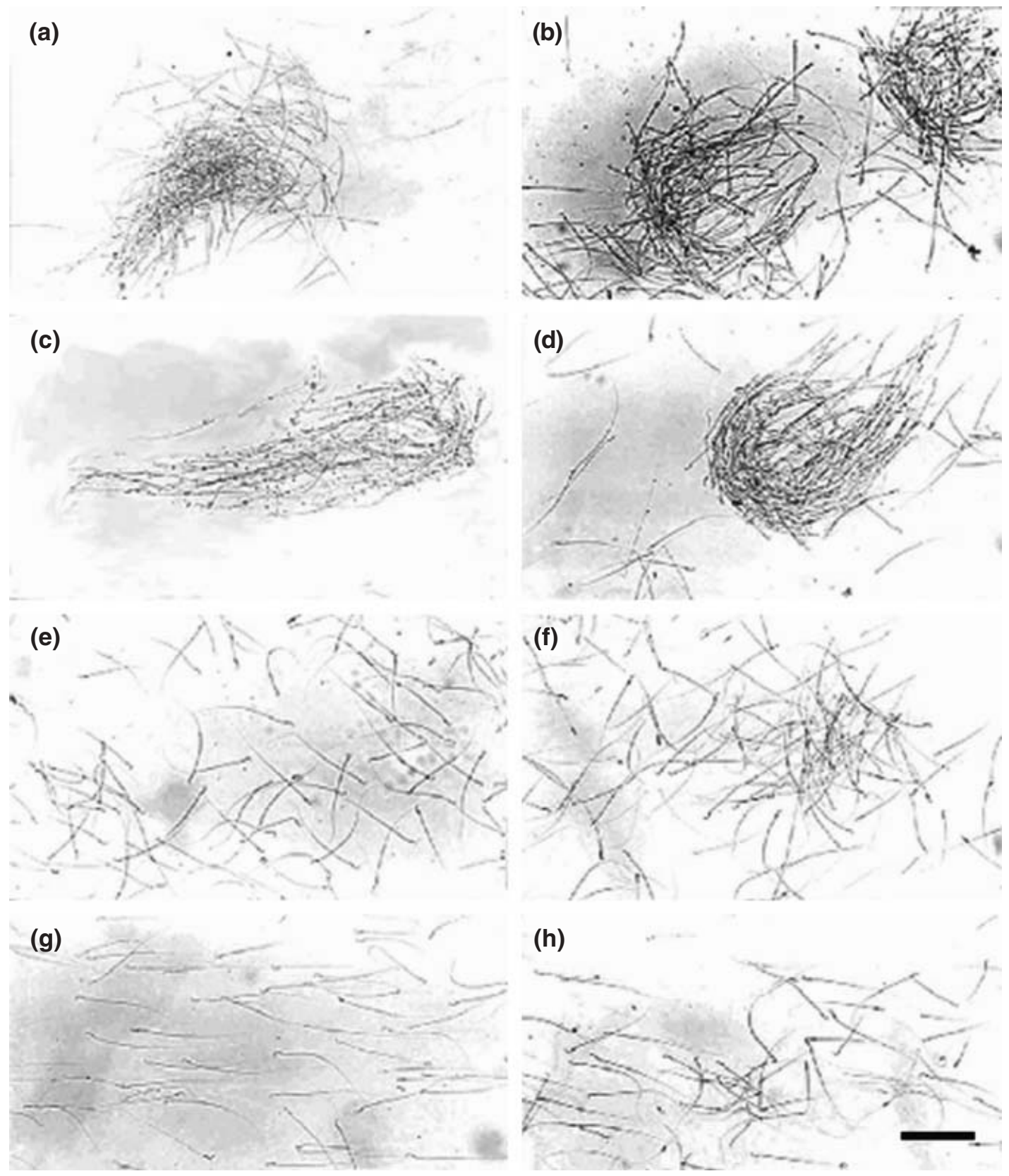

Fig. 5. Time- and dose-dependent agglutination of rat spermatozoa with polyclonal antibody. Agglutination patterns were recorded with different concentrations of antibody (a,b: $350.0 \mu \mathrm{g}$; c,d: $35.0 \mu \mathrm{g}$; e,f: $3.5 \mu \mathrm{g}$; g,h: $0.35 \mu \mathrm{g})$ after $30 \mathrm{~min}(\mathrm{a}, \mathrm{c}, \mathrm{e}, \mathrm{g})$ and $60 \mathrm{~min}(\mathrm{~b}, \mathrm{~d}, \mathrm{f}, \mathrm{h})$. Note that at same concentration of antibody $(3.5 \mu \mathrm{g}$, $\mathrm{e}, \mathrm{f})$ but shorter incubation (e; $30 \mathrm{~min}$ ) versus longer incubation ( $f ; 60 \mathrm{~min})$, there were more agglutinates. Scale bar represents $100 \mu \mathrm{m}$.

Pab localizes to the antigen on the mid-piece of the spermatozoa. The preimmune serum did not show any staining on the spermatozoa.

The time- and dose-dependent agglutination of rat spermatozoa with polyclonal antibody (Fig. 5) shows that after 30 min of incubation, rat spermatozoa agglutinate and form a comet shaped agglutinate. This type of agglutination was evident only in spermatozoa incubated with $350 \mu \mathrm{g}$ and $35 \mu \mathrm{g}$ Pab (Fig. 5a, c); however, incubation for $1 \mathrm{~h}$ with $3.5 \mu \mathrm{g}$ Pab has the same effect (Fig. 5f), but incubation with $0.35 \mu \mathrm{g}$ Pab resulted in almost no agglutination even after $1 \mathrm{~h}$ of incubation (Fig. 5h).

The antibody did not show crossreactivity with proteins from the somatic tissues, brain, kidney, liver, spleen, thymus and heart, and the accessory reproductive 
(a)

$\mathrm{kDa}$

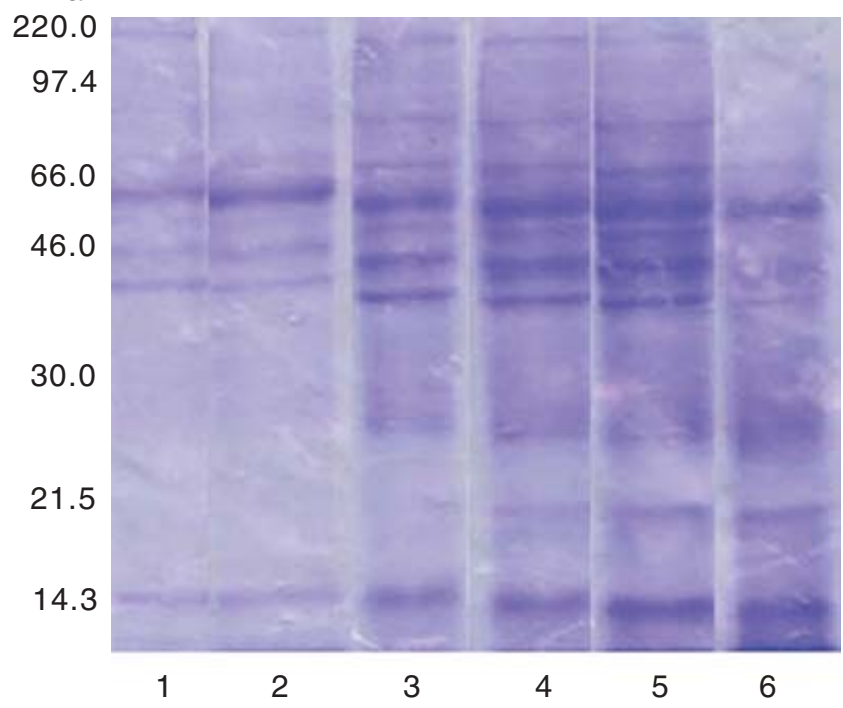

(b)

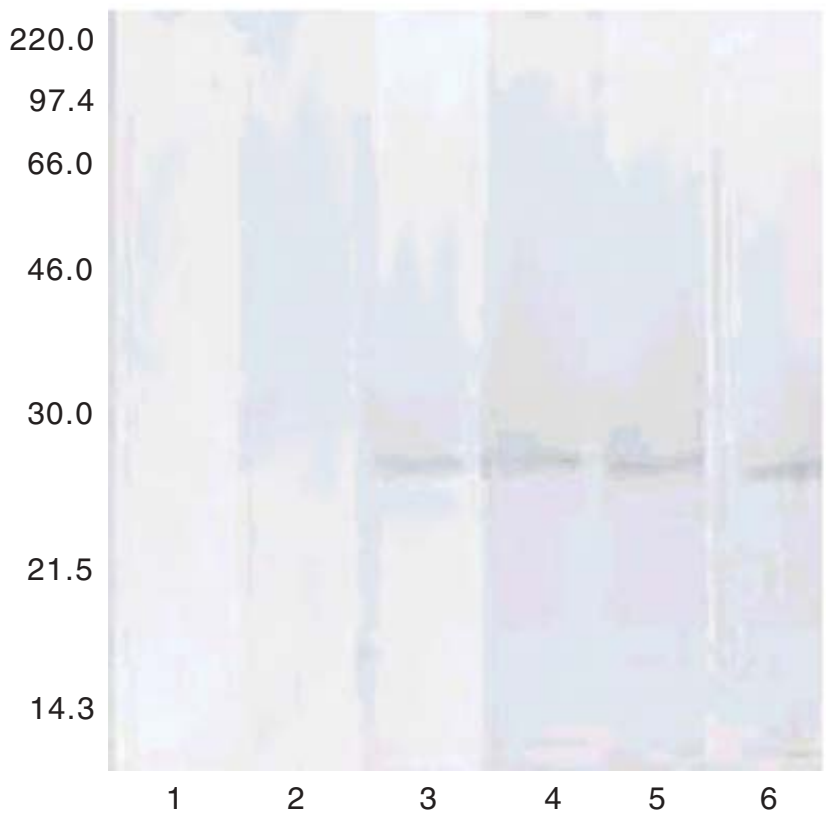

Fig. 6. (a) SDS-PAGE and (b) western blot analysis showing developmental expression of the $27 \mathrm{kDa}$ epididymal protein identified by polyclonal antibody. Epididymal proteins from rats at 20 (lane 1), 30 (lane 2), 40 (lane 3), 50 (lane 4), 60 (lane 5) and 80 days (lane 6) of age were subjected to (a) SDS-PAGE and (b) western blot analysis. Note that the protein is detected first on day 40 (lane 3)

tract tissue proteins, like seminal vesicle and prostrate gland using both immunohistochemistry and western blot analysis (data not shown).

\section{Developmental expression study of protein}

SDS-PAGE and western blot analysis of the protein extracted from the corpus epididymidis of mice aged 20,
30, 40, 50, 60 and 80 days (Fig. 6). The protein becomes apparent from day 40 .

\section{Castration and DHT supplementation}

Immunohistochemical analysis of proteins from different regions of epididymis at days 7, 14 and 21 after castration (Fig. 7) showed that there was no staining in the caput epididymidis. The protein content gradually reduces and is absent at day 21 after castration in the corpus and cauda epididymides.

DHT supplementation was carried out at different times as described earlier to ascertain the involvement of testicular androgen in the control of epididymal expression of the $27 \mathrm{kDa}$ protein. Western blot analysis showed that, in group 1, expression of the protein was normal until day 21 after the insertion of the implant (Fig. 8, lanes A1-A3). Lane A represents the control rat epididymal protein. In groups 2-4 (Fig. 8, lanes B1-B3, C1-C3 and D1-D3) the protein gradually reappeared on DHT supplementation.

\section{Discussion}

The results of the present study using polyclonal antibodies characterized an androgen-dependent and developmentally regulated epididymal protein. A number of epididymis-specific proteins have been identified, and shown to have an important role in posttesticular maturation of spermatozoa (Bedford et al., 1973). Epididymal proteins interact with spermatozoa and modify their surface properties during epididymal transit (Gonzalez et al., 1982; Olson et al., 1987; Mathieu et al., 1992; Haidl et al., 1993; Neito et al., 1997). Several studies have clearly established that the acquisition of motility and fertility by spermatozoa in the epididymis is not intrinsic to sperm cells, but rather is dependent upon the interaction of spermatozoa with proteins synthesized and secreted by the epididymal epithelium. Moore et al. (1994) showed that a $26 \mathrm{kDa}$ antigen on the tail of cauda epididymal spermatozoa is derived from the secretions of the epididymal epithelium. There is direct evidence to show that there is sequence identity between the protein secreted by the epididymis and a protein of the sperm plasma membrane recognized by monoclonal antibody 4E9 (Xu et al., 1997). A 26 kDa glycoprotein secreted by the proximal epididymis has been shown to be acquired by the spermatozoa. This protein is localized on the anterior head region overlying the acrosome. Antibodies to this $26 \mathrm{kDa}$ protein block sperm-zona pellucida binding in a species-specific manner (Begin et al., 1995). Several proteins of 26 to $27 \mathrm{kDa}$ have been identified in a two-dimensional gel electrophoresis study and amino terminal sequence of some of these proteins was found to have sequence 

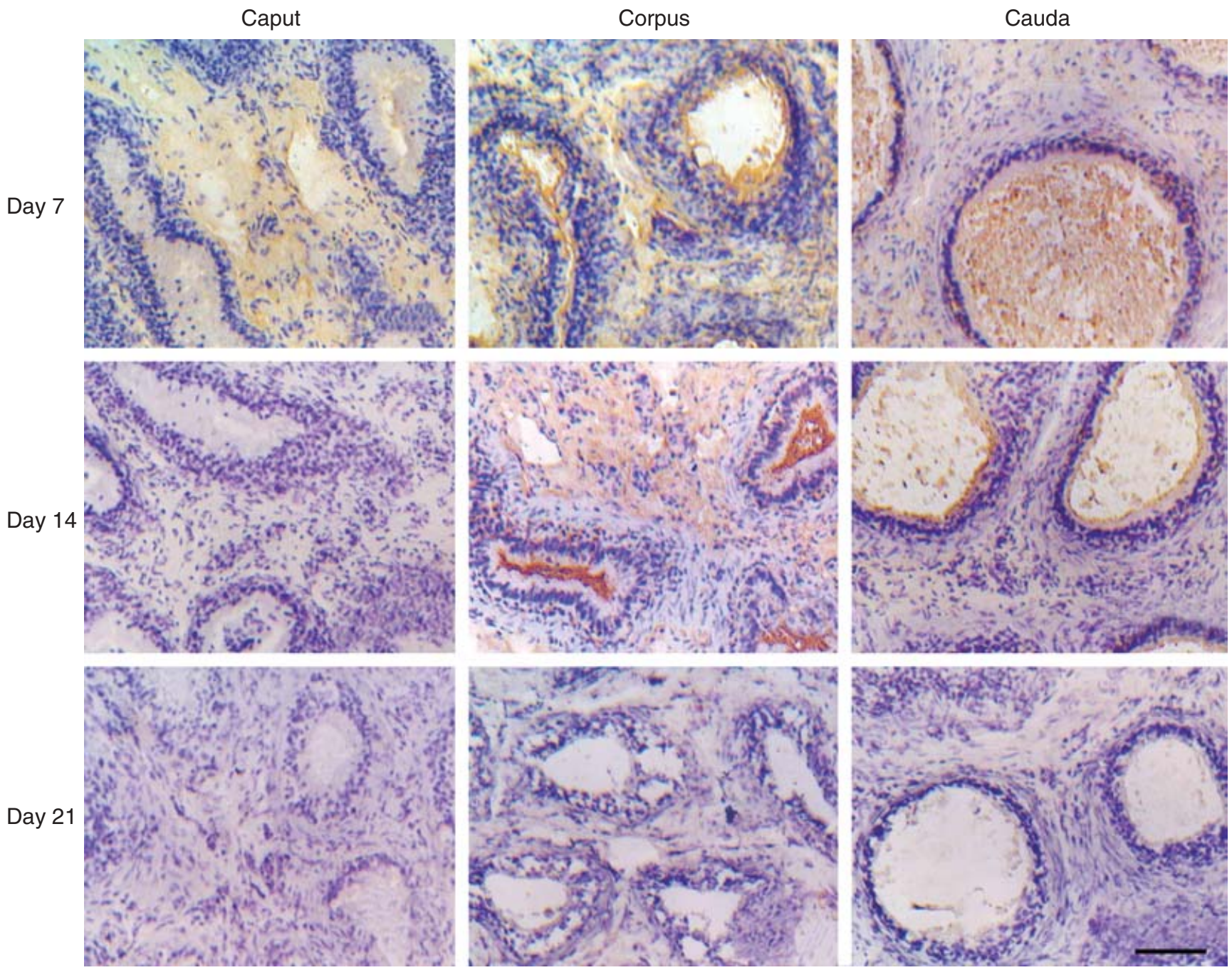

Fig. 7. Immunohistochemical localization of the $27 \mathrm{kDa}$ epididymal protein at days 7,14 and 21 after castration in rats in caput, corpus and cauda epididymides. Note that the protein localized by the polyclonal antibody starts to decline in both corpus and cauda epididymides and is undetectable at day 21 after castration. Staining was not observed in the caput epididymidis. Scale bar represents $100 \mu \mathrm{m}$.

similarity with HE1 (human), ESP 14.6 (primates) and EP4 in pig spermatozoa (Syntin et al., 1996).

In the present study, an epididymis-specific protein of approximately $27 \mathrm{kDa}$ was identified using sera from mice that were neonatally tolerized against testicular protein and immunized with epididymal protein (Khole et al., 2000). A polyclonal antibody to this protein was raised in rabbits. The polyclonal antibody did not show any crossreactivity with rat testis as demonstrated by ELISA, western blot analysis and immunohistochemistry. Immunohistochemical analysis showed that the antibody did not localize to any protein in the caput epididymides. The antibody localized to the protein in the epithelium of corpus epididymidis and on spermatozoa from corpus and cauda epididymides. These results indicate that this protein is secreted mainly in the corpus epididymidis and acquired by spermatozoa during passage through these regions. The presence of the protein in corpus and cauda epididymides may be due to its secretion by the principal cells of the corpus epididymidis. The principal cells of the corpus epididymidis have a well developed endoplasmic reticulum and Golgi apparatus, which indicates that they are involved in active protein synthesis. There are some reports in which principal cells of the epididymis have been shown to incorporate labelled amino acids and transport radiolabelled molecules through the cell (Flickinger et al., 1979, 1981). Principal cells are actively involved in the physiological functions of the epididymides involving endocytosis (Hermo et al., 1998) and secretion (Legare et al., 1999). Proteins secreted by principal cells may interact with spermatozoa in the lumen of epididymal duct and enable spermatozoa to develop motility (Jaiswal and Majumder, 1998) and fertility (Smithwick and Young, 
$\mathrm{kDa}$

220.0

97.4

66.0

46.0

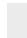

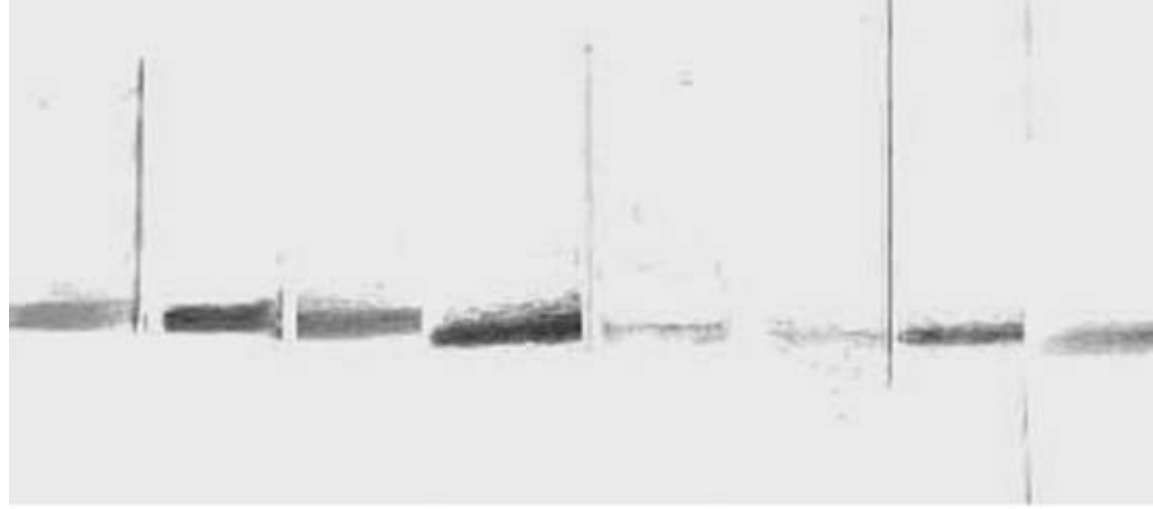

14.3

A

A1

A2

A3

B

B1

B2

B3

220.0

97.4

66.0

46.0

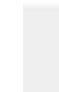

30.0

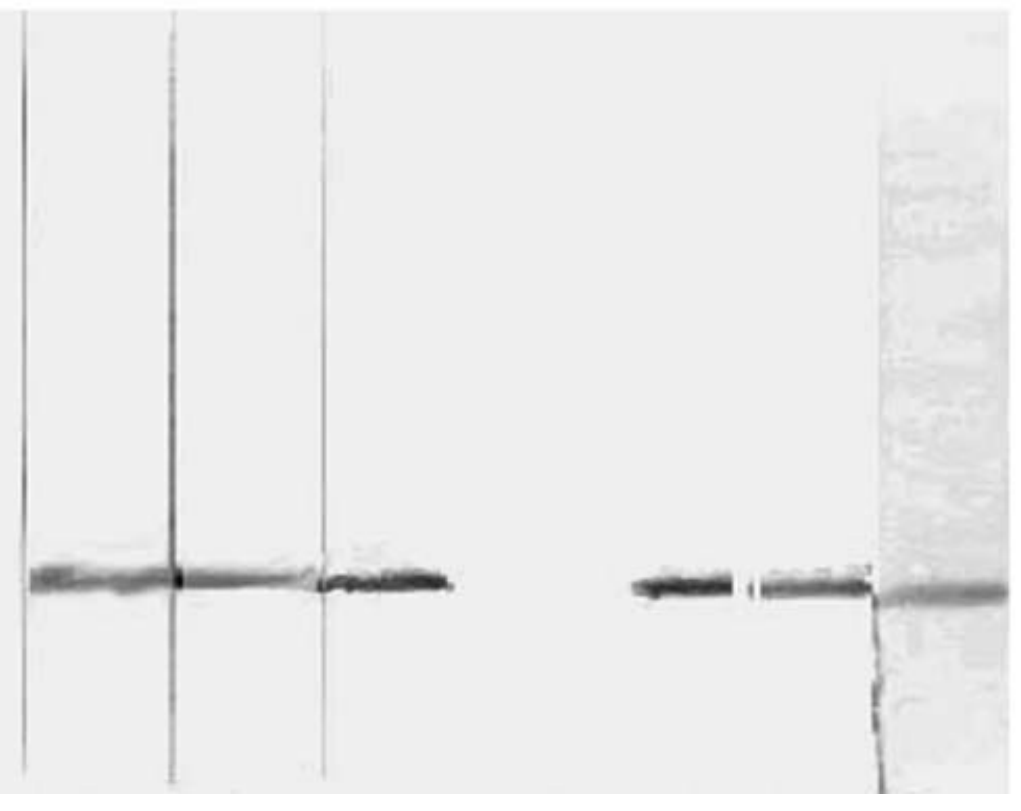

14.3

C

C1

C2

C3

D D1

D2

D3

Fig. 8. Western blot analysis illustrating the effect of castration and dihydrotestosterone (DHT) supplementation. Proteins extracted from whole epididymides of rats from different groups were subjected to western blot analysis. Lane A: epididymal proteins from control animals; lanes A1-A3: epididymal proteins from group 1 animals; lane B: epididymal proteins at day 7 after castration; lanes B1-B3: epididymal proteins from group 2 animals; lane C: epididymal protein at day 14 after castration; lanes C1-C3: epididymal protein from group 3 animals; lane D: epididymal proteins at day 21 after castration; lanes D1-D3: epididymal proteins from group 4 animals. Note that in group 1, (lanes A1-A3) protein content is similar to that of non-castrated control (lane A). In group 2 , protein was considerably reduced at day 7 after castration (lane B) and continues to be so even 7 days after DHT implant insertion (lane B1). Concentration of the protein is increased at days 14 and 21 after DHT implant insertion (lanes B2-B3). In groups 3 and 4, the protein was absent at days 14 and 21 after castration (lanes $C$ and D). The protein was detectable on days 7, 14 and 21 after insertion of DHT implant (lanes C1-C3 and D1-D3). 
1999). In the present study, the highest protein content was detected in the corpus epididymidis. This pattern of immunoreactivity is similar to a protein identified in mouse MEP7 (Rankin et al., 1992) and CP27 (Flickinger et al., 1988). However, protein MEP7 appears in the epithelium of cauda epididymidis, whereas the protein under study is specifically localized only in corpus epididymal epithelium, as demonstrated by immunohistochemistry. Indirect immunofluorescence was used to show that the protein is localized on the surface of rat spermatozoa. This observation was confirmed by agglutination in vitro. In this assay, there was a time- and concentration-dependent agglutination of rat spermatozoa.

Earlier studies have shown that development of epididymal structure and functions is regulated by testicular factors, especially androgens. In the present study, castration of rats followed by DHT supplementation revealed that the expression of the protein is under the control of testosterone. Similar studies carried out by other investigators show the effect of castration and androgen supplementation on protein synthesis and secretion by using $\left.{ }^{35} \mathrm{~S}\right]$ methionine uptake followed by SDS-PAGE in the epididymis (Jones et al., 1980; Holland and Orgebin-Crist, 1988; Ghyselinck et al., 1989; Holland et al., 1992). Two ram cauda epididymal maturation-dependent sperm glycoproteins were undetectable after orchidectomy, but reappeared after testosterone supplementation (Gatti et al., 2000). Kirchhoff et al. (2000) have shown by in vitro culture that mRNA expression of CD52 protein is under the control of androgen and temperature.

Androgen regulation and acquisition of this protein by spermatozoa during epididymal transit indicates that CD52 is likely to have a role in sperm maturation. It has been shown that the junction of the corpus and cauda epididymides plays a major role in sperm maturation (Phelps and Myles, 1987; Anakwe et al., 1991; Setchell et al., 1994). The fertilization rate is higher in spermatozoa from corpus than that from caput epididymides, as seen in IVF (Mahadevan and Trounson, 1985; Pryor, 1987). Sperm motility and pregnancy rates were also significantly improved when the vas deferens was surgically joined to the corpus epididymidis in patients who received specific tubule vasoepididymostomy for obstructive azoospermia (Fogdestam et al., 1986; Schoysman and Bedford, 1986; Silber, 1989). As spermatozoa become motile and fertile in the corpus and cauda epididymides, the protein identified in the present study is probably a sperm maturation protein.

The physiological and biochemical aspect of epididymal functions have been studied by several workers (Zhao et al., 1993; Hinton and Palladino, 1995; Suzuki et al., 1996); however, the mechanisms governing development of the epididymis from newborn to maturity have not been studied in detail. The developmentally regulated expression of the epididymal proteins is also a classical phenomenon (Premchandran and Hegde, 1991; Liu et al., 1992; Chen et al., 1999). The expression of protein identified in the present study was regulated developmentally. The insignificant amounts of this protein in neonatal epididymides indicate that it does not have a major role in the early postnatal period.

The role of proteins secreted by the epididymis in maturation of sperm function and fertilization has been investigated. These investigations were carried out using monospecific antibodies (Yeung et al., 1997; Focarelli et al., 1998; Martin et al., 1998). It has also been reported that sperm maturation proteins secreted in the epididymal region play an important role in the development of motility and fertility. Epididymisspecific androgen-regulated proteins are potential targets for contraception because of their possible role in sperm maturation. However, the mechanisms by which epididymal proteins implement the acquisition of sperm motility and fertilizing ability are generally unknown and need to be studied.

The $27 \mathrm{kDa}$ protein is an epididymis-specific protein that has characteristics of a protein involved in sperm maturation and is secreted from an epididymal region in which maturation is known to take place. The protein is acquired by the spermatozoa and its synthesis is androgen-regulated. Availability of large quantities of this protein is a prerequisite for any further investigations. Therefore, cloning and overexpression of this androgenregulated epididymis-specific protein need to be undertaken.

The authors wish to sincerely thank C. P. Puri, Director, National Institute for Research in Reproductive Health for continued interest and encouragement. S. A. Joshi would like to acknowledge the award of research fellowship from the Department of Atomic Energy (Board for Research in Nuclear Sciences) during the tenure of this study. This study was funded by research grant from the Department of Atomic Energy (Board for Research in Nuclear Sciences) (99/ 37/ 19/ BRNS Cell), Government of India.

\section{References}

Amann RP, Hammerstedt RH and Veeramachaneni DN (1993) The epididymis and sperm maturation: a perspective Reproduction, Fertility and Development 5 361-381

Anakwe OO, Sharma S, Hoff HB, Hardy DM and Gerton GI (1991) Maturation of guinea-pig sperm in the epididymis involves the modification of proacrosin oligosaccharide side chains Molecular Reproduction and Development 29 294-301

Batova IN, Ivanova MD, Mollova MV and Kyurkchiev SD (1998) Human sperm surface glycoprotein involved in human sperm-zona pellucida interaction International Journal of Andrology 21 141-153

Bedford JM and Kim HH (1993) Sperm-egg binding patterns and oocyte cytology in retrospective analysis of fertilization failure in vitro. Human Reproduction 8 453-463

Bedford JM, Calvin H and Cooper WG (1973) The maturation of spermatozoa in the human epididymis Journal of Reproduction and Fertility Supplement 18 199-213

Begin S, Berube B, Boue F and Sullivan R (1995) Comparative immunoreactivity of mouse and hamster sperm proteins recognized by an anti-P26h 
hamster sperm protein Molecular Reproduction and Development $4 \mathbf{1}$ 249-256

Blaquier JA, Cameo MS, Stephany D, Piazza A, Tezon J and Sherins RJ (1987) Abnormal distribution of epididymal antigens on spermatozoa from infertile men Fertility and Sterility 47 302-309

Boue F and Sullivan R (1996) Cases of human infertility are associated with the absence of $\mathrm{P} 34 \mathrm{H}$, an epididymal sperm antigen Biology of Reproduction 54 1018-1024

Boue F, Duquenne C, Lassalle B, Lefevre A and Finaz C (1995) FLB1, a human protein of epididymal origin that is involved in sperm-oocyte recognition process Biology of Reproduction 52 267-278

Burkin HR and Miller DJ (2000) Zona pellucida protein binding ability of porcine sperm during epididymal maturation and acrosome reaction Developmental Biology 222 99-109

Castle PE, Whaley KJ, Hoen TE, Moench TR and Cone RA (1997) Contraceptive effect of sperm agglutinating monoclonal antibodies in rabbits Biology of Reproduction $\mathbf{5 6}$ 153-159

Chen MY, Carpenter D and Zhao CQ (1999) Expression of bone morphogenetic protein 7 in murine epididymis is developmentally regulated Biology of Reproduction 60 1503-1508

Cooper TG (1986) Function of the epididymis and its secretory products. In The Epididymis, Sperm Maturation and Fertilization pp 1-8 SpringerVerlag, New York

Cooper TG (1995) Role of epididymis in mediating changes in male gamete during maturation Advances in Experimental Medicine and Biology 377 87-101

Cornwall GA, Orgebin-Crist MC and Hann SR (1992) The CRES gene: a unique testis-regulated gene related to cystatin family is highly restricted in its expression to the proximal region of the mouse epididymis Molecular Endocrinology 6 1653-1664

Dacheux JL, Chevrier C and Lanson Y (1987) Motility and surface transformations of human spermatozoa during epididymal transit Annals of New York Academy of Sciences 513 560-562

Ensrud KM and Hamilton DW (1991) Use of neonatal tolerization and chemical immunosupression for the production of monoclonal antibodies to maturation specific sperm surface molecule Journal of Andrology 12 305-314

Flickinger CJ (1979) Synthesis, transport and secretion of protein in the initial segment of the mouse epididymis as studied by electron microscope radioautography Biology of Reproduction 20 1015-1030

Flickinger CJ (1981) Regional differences in synthesis, intracellular transport and secretion of protein in mouse epididymis Biology of Reproduction 2 871-883

Flickinger CJ, Herr JC and Klotz KL (1988) Immunocytochemical localization of the major glycoprotein of epididymal fluid from the cauda in the epithelium of the mouse epididymis Cell Tissue Research $\mathbf{2 5 1}$ $603-610$

Focarelli R, Giuffrida A, Capparelli S, Scibona M, Fabris FM, Francavilla F, Francavilla S, Giovampaola CD and Rosati F (1998) Specific localization in the equatorial region of gp20, a $20 \mathrm{kDa}$ sialylglycoprotein of the capacitated human spermatozoa acquired during epididymal transit which is necessary to penetrate zona-free hamster egg Molecular Human Reproduction 4 119-125

Fogdestam I, Fall M and Nilsson S (1986) Microsurgical epididymovasostomy in the treatment of occlusive azoospermia Fertility and Sterility 46 925-929

Gatti JL, Druart X, Syntin P, Guerin Y, Dacheux JL and Dacheux F (2000) Biochemical characterization of two ram cauda epididymal maturation dependent sperm glycoprotein Biology of Reproduction 62 950-958

Ghyselinck NB, Jimenez C, Courty Y and Dufaure JP (1989) Androgendependent messenger RNA(s) related to secretory proteins in the mouse epididymis Journal of Reproduction and Fertility 85 631-639

Gonzalez Echeverria FM, Cuasnicu PS and Blaquier JA (1982) Identification of androgen dependent glycoproteins in the hamster epididymis and their association with spermatozoa Journal of Reproduction and Fertility $641-7$

Haidl G, Badura B, Hinsch KD, Ghyczy M, Gareiss J and Schill WB (1993) Disturbances of sperm flagella due to failure of epididymal maturation and their possible relationship to phospholipids Human Reproduction 8 1070-1073

Hayashi M, Fujimoto S, Takano H et al. (1996) Characterization of a human glycoprotein with a potential role in sperm-egg fusion: cDNA cloning, immunohistochemical localization and chromosomal assignment of the gene (AEGL 1) Genomics 32 367-374

Hermo L, Barin K and Oko R (1998) Androgen binding protein secretion and endocytosis by principal cells in the adult rat epididymis and during postnatal development Journal of Andrology 19 527-541

Hinton BT and Palladino MA (1995) Epididymal epithelium: its contribution to the formation of a luminal fluid microenvironment Microscopic Research Technology 30 67-81

Holland MK and Orgebin-Crist MC (1988) Characterization and hormonal regulation of protein synthesis by the murine epididymis Biology of Reproduction 38 487-496

Holland MK, Vreeburg JT and Orgebin-Crist MC (1992) Testicular regulation of epididymal protein secretion Journal of Andrology 13266 273

Jaiswal BS and Majumder GC (1998) Biochemical parameters regulating forward motility initiation in vitro in goat immature epididymal spermatozoa Reproduction, Fertility and Development 10 299-307

Jones R, Brown CR, Von Glos KI and Parker MG (1980) Hormonal regulation of protein synthesis in the rat epididymis: characterization of androgen dependent and testicular fluid dependent proteins Journal of Biochemistry 188 667-676

Khole V, Joshi SA and Sapna Singh (2000) Identification of epididymis specific antigen by neonatal tolerization American Journal of Reproductive Immunology 44 350-356

Kirchhoff C, Habben I, Ivell R and Krull N (1991) A major human epididymis specific CDNA encodes a protein with sequence homology to extracellular proteinase inhibitors Biology of Reproduction 45350 357

Kirchhoff C, Carballada R,Harms B and Kascheike I (2000) CD52 mRNA is modulated by androgens and temperature in epididymal cell culture Molecular Reproduction and Development 56 26-33

Kirszbaum L, Sharpe JA, Murphy B, d'Apice AJ, Classon B, Hudson P and Walker ID (1989) Molecular cloning and characterization of novel, human complement-associated protein SP40, 40: a link between the complement and reproductive systems The EMBO Journal 8 711-718

Laemmli UK (1970) Cleavage of structural proteins during the assembly of the head of bacteriophage T4 Nature 15 680-685

Legare C, Gaudreault C, St-Jacques S and Sullivan R (1999) P34H sperm protein is preferentially expressed by the human corpus epididymides Endocrinology 140 3318-3327

Liu HW, Sun GH, Shy SR and Shyu HY (1992) Post natal development and testosterone dependence of GP-83 and GP-49, two sperm maturation related glycoproteins in Balb/c mouse epididymis Cell Tissue Research 269 189-194

Lowry OH, Rosenborough NJ, Farr AL and Randall RJ (1951) Protein measurement with Folin phenol reagent Journal of Biological Chemistry $193206-275$

Lunde T, Christiansen E and Purvis E (1990) Epididymis. Anatomy function and pathology Tidsskr Nor Laegeforen 110 3119-3123

Mahadevan MM and Trounson AO (1985) Removal of the cumulus oophorus from the human oocyte for in vitro fertilization Fertility and Sterility 43 263-267

Martin Ruiz C, Duquenne C, Treton D, Lefevre A and Finaz C (1998) SOB3, a human sperm protein involved in zona pellucida binding: physiological and biochemical analysis, purification Molecular Reproduction and Development 49 286-297

Mathieu C, Guerin JF, Cognat M, Lejeune H, Pinatel MC and Lornage J (1992) Motility and fertilizing capacity of epididymal human spermatozoa in normal and pathological cases Fertility and Sterility $\mathbf{5 7}$ 871-876

Moore A, Ensrud KM, White TW, Frethem CD and Hamilton DW (1994) Rat epididymis specific sperm maturation antigens. Evidence that the $26 \mathrm{kDa} 4 \mathrm{E} 9$ antigen found on rat caudal epididymal sperm tail is derived 
from a protein secreted by epididymis Molecular Reproduction and Development 37 181-194

Moore HD (1998) Contribution of epididymal factors to sperm maturation and storage Andrologia 30 233-239

Neito A, Gutierez S and Martinez MP (1997) Isolation and characterization of rabbit epididymal secretory glycoprotein that associates to the spermatozoon surface Molecular Reproduction and Development $\mathbf{4 6}$ 337-343

Olson GE, Lifsics MR, Winfrey VP and Rifkin JM (1987) Modification of rat sperm flagellar plasma membrane during maturation in epididymis Journal of Andrology 8 129-147

Parent S, Lefievre L, Brindle Y and Sullivan R (1999) Bull subfertility is associated with low levels of a sperm membrane antigen Molecular Reproduction and Development 52 57-65

Parte $\mathbf{P}$ and Juneja HS (1992) Temporal changes in serum levels of gonadotrophins and testosterone in male rats bearing subcutaneous implants of $5 \alpha$-DHT International Journal of Andrology 15 355-364

Phelps BM and Myles DG (1987) The guinea-pig sperm plasma membrane protein, $\mathrm{PH} 20$, reaches the surface via two transport pathways and becomes localized to a domain after an initial uniform distribution Developmental Biology 123 63-72

Poulton TA, Everard D, Baxby K and Parslow JM (1996) Characterization of a sperm coating autoantigen reacting with antisperm antibodies of infertile males using monoclonal antibodies British Journal of Obstetrics and Gynecology 103 463-467

Premchandran S and Hegde UC (1991) Ontogeny of mouse caudal proteins identified by a monoclonal antibody Human Reproduction 6 589-592

Pryor JP (1987) Surgical retrieval of epididymal spermatozoa Lancet 21341

Rankin TL, Tsuruta KJ, Holland MK, Griswold MD and Orgebin-Crist MC (1992) Isolation, immunolocalization and sperm association of three proteins of 18, 25 and $29 \mathrm{kDa}$ secreted by mouse epididymis Biology of Reproduction 46 747-766

Schoysman RJ and Bedford JM (1986) The role of the human epididymis in sperm maturation and sperm storage as reflected in the consequences of epididymovasostomy Fertility and Sterility 46 293-299

Setchell BP, Maddocks S and Brooks DE (1994) Anatomy, vasculature, innervation and fluids of the male reproductive tract. In The Physiology of Reproduction pp 1063-1175 Eds E Knobil and JD Neill. Raven Press, New York

Silber SJ (1989) Role of epididymis in sperm maturation Urology 33 47-51

Smithwick EB and Young LG (1999) Immunohistochemical localization of epididymal secretory glycoprotein EP1 in the adult male chimpanzee Tissue Cell 31 54-65

Suzuki A, Matsuzawa A and Iguchi T (1996) Downregulation of Bcl-2 is the first step on Fas-mediated apoptosis of male reproductive tract Oncogene 13 31-37

Syntin P, Dacheux F, Druart X, Gatti JL, Okamura N and Dacheux JL (1996) Characterization and identification of proteins secreted in the various regions of the adult boar epididymis Biology of Reproduction $55956-$ 974

Towbin H, Stachlin T and Gordon J (1979) Electrophoretic transfer of proteins from polyacrylamide gel to nitrocellulose sheet: procedures and some applications Proceeding National Academy of Sciences USA 76 4350-4354

Xu W, Ensrud KM and Hamilton DW (1997) The 26 kD protein recognized on rat cauda epididymal sperm by monoclonal antibody $4 \mathrm{E} 9$ has internal peptide sequence that is identical to the secreted form of epididymal protein E 1 Molecular Reproduction and Development 46 377-382

Yeung CH, Perez- Sanchez F, Soler C, Poser D, Kliesch S and Cooper TG (1997) Maturation of human spermatozoa (from selected epididymides of prostatic carcinoma patients) with respect to their morphology and ability to undergo the acrosome reaction Human Reproduction Update 3 205-213

Zhao GQ, Zhou X, Eberspaecher H, Solursh M and de Crombrugghe B (1993) Cartilage homeoprotein I, a homeoprotein selectively expressed in chondrocytes Proceeding National Academy of Sciences USA 90 8633-8637

Received 23 August 2002.

First decision 18 November 2002.

Revised manuscript received 16 December 2002.

Accepted 20 December 2002. 